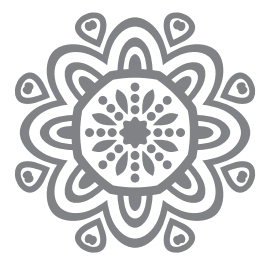

\title{
Epsitemologi Penafsiran Musdah Mulia Tentang Homoseksual
}

\author{
Nur Rofiah', Abd. Muid N. ${ }^{2}$, dan Ahmad Royhan Firdausy ${ }^{3}$ \\ ${ }^{1)}{ }^{2)}$ Dosen UIN Syarif Hidayatullah Jakarta DPK Institut PTIQ Jakarta \\ 3) Magister Ilmu Al-Quran dan Tafsir Institut PTIQ Jakarta \\ 1) balesaloe@gmail.com, ${ }^{3)}+6281287074041$
}

\begin{abstract}
The homosexual controversy not only shook the principles in Islam, but also the principles of religion besides Islam, especially Christians and Jews. Allegedly, the culture that became the background of each religion was similar, giving birth to a similar shock. Therefore, even though orthodoxy, homosexuality is considered complete, the controversy about this is still pulsing. One thinker who is trying to find a new perspective on homosexuality is Musdah Mulia. This study is about to unravel Musdah Mulia's epistemology in developing his arguments about homosexuality and how Musdah Mulia interpreted the verses of the Al-Quran relating to homosexuality
\end{abstract}

Keywords: sexuality, homosexuality, Easy Noble 


\section{Pendahuluan}

Manusia sebagai makhluk biologis memiliki berbagai kebutuhan, salah satunya adalah kebutuhan seksual. Terkhusus dalam perihal seksualitas, manusia memiliki dorongan syahwat yang muncul bersamaan dengan masa baligh dan bersifat instinktif (alamiah/sunnatullah). Gejolak itu semestinya dirawat dan diarahkan sesuai dengan aturan-aturan syari'at. Sebab, salah satu kelemahan terbesar manusia adalah persoalan seksual. Maksud dari kelemahan di sini ialah problem dalam mengendalikan naluri seksual yang kemudian membawa pada pelampiasan secara tidak sah, brutal, dan biadab serta penyimpangan seksual yang tak beraturan. Maka wajar apabila Al-Qur'an memberikan aturan-aturan yang sesuai dengan martabat kemuliaan manusia. ${ }^{1}$

Berkaitan dengan seks, permasalahan yang banyak didiskusikan akhirakhir ini yaitu tentang homoseksualitas. Beberapa kalangan memandang homoseksualitas merupakan perbuatan sangat rendah dan dianggap melampui batas, yang dalam Al-Qur'an termsuk dalam katagori fahisyah (perbuatan keji). Demikian juga disebut dengan tindakan yang melampui batas (israf) ${ }^{2}$. Bahkan pengutukan atau pelaknatan yang dilakukan Tuhan sangatlah keras kepada para pelaku homoseksualitas (liwat) yang layak diberikan hukum yang amat mengerikan untuknya. ${ }^{3} \mathrm{Hal}$ ini didasarkan pada sabda Rasulullah Saw. Yang diriwayatkan oleh Ibnu Abbas, "Allah melaknat siapa saja yang melakukan perbatan kaum Luth, (beliau mengulanginya sebanyak tiga kali).” (HR. Nasa'i dalam As-Sunan Al-Kubra). ${ }^{4}$

Menurut Abdul Mustaqim, berdasarkan ayat Al-Qur'an dan hadis yang dikaji secara holistik dan tematik, disimpulkan bahwa tidak ada celah sedikit pun untuk melegalkan praktik homoseksual, meskipun dengan dalih menghormati HAM (Hak Asasi Manusia). ${ }^{5}$ Para ulama pun sepakat bahwa perilaku homoseksual dan lesbian adalah haram, meskipun mereka berbeda pendapat dalam menetapkan hukuman apa yang harus diberikan kepada para pelaku. ${ }^{6}$

1 Departemen Agama RI, Membangun Keluarga Harmonis: Tafsir Al-Qur'an Tematik, Jakarta: Departemen Agama RI, 2008, hal. 11-15.

2 Abdul Mustaqim, "Homoseksual Dalam Perspektif Al-Qur’an: Pendekatan Tafsir Kontekstual al-Maqashidi," Jurnal Suhuf, Vol.9, No.1, Juni 2016, hal.52

3 Abdelwahab Bouhdiba, Sexuality in Islam: Peradaban Kamasutra Abad Pertengahan, terj. Ratna Maharani Utami, Yogyakarta: Alenia, 2004, hal. 65

4 Rama Azhari dan Putra Kencana, Membongkar Rahasia Jaringan Cinta Terlarang Kaum Homoseksual, Jakarta: Hujjah Press, 2008, hal. 31.

5 Abdul Mustaqim, “Homoseksual Dalam Perspektif Al-Qur’an: Pendekatan Tafsir Kontekstual al-Maqashidi”, SUHUF: Jurnal Kemenag, Vol. 9, No. 1, Juni 2016, hal. 55-56.

${ }^{6}$ Abdul Mustaqim, “Homoseksual Dalam Perspektif Al-Qur'an: Pendekatan Tafsir Kontekstual al-Maqashidi”, SUHUF: Jurnal Kemenag, Vol. 9, No. 1, Juni 2016, hal. 56. 
Alasan yang sering dipakai untuk menyatakan pelarangan adalah bahwa homoseksualitas merupakan kerusakan moral dan penyakit moral. Homoseksualitas dilarang karena sangat berbahaya bagi kesehatan individu dan kesehatan masyarakat. Secara teologis ${ }^{7}$, para ulama yang menolak homoseksualitas akan merujuk cerita Luth dalam Al-Qur'an dan sejumlah hadis nabi. Berbagai penafsiran akan lahir dari kisah kaum nabi Luth. Padahal, ayat-ayat yang memuat kisah kaum nabi Luth di dalam Al-Qur'an tidak menyebut secara eksplisit hubungan seksual sesama jenis. Kata dalam Al-Qur'an yang sering digunakan untuk merujuk hubungan seksual sesama jenis adalah al-Fahisyah, al-Khabaits, al-Munkar dan as-Sayyiat. ${ }^{8}$

Oleh sebab itu, tidak dapat dipungkiri bahwa produk tafsir yang ditulis oleh masing-masing penafsir memiliki kandungan isi yang beragam, atau dengan kata lain, ayat ayat yang berkaitan dengan kisah nabi luth menjadi multi tafsir.

Salah satu penafsiran kontemporer yang kerap menjadi perdebatan ialah dari Musdah Mulia yang berpendapat bahwa homoseksual sesungguhnya bukanlah "liwath" atau "luth" yang dewasa ini dikenal dengan sodomi. Dua istilah yang merujuk pada relasi seksual yang pernah dilakukan kaum Nabi Luth (man amila amala qawm Luth). Homoseksual adalah orientasi seksual kepada sejenis, sementara liwath (sodomi) adalah perilaku seksual yang menyasar ke anus, bukan ke vagina. Oleh sebab itu, tindakan homoseksual tidak bisa disetarakan hukuman dan perlakuannya dengan kaum sodom baik secara sosial maupun hukum. Sebab, homoseksual adalah orientasi seksual kepada sejenis, sementara liwath (sodom) adalah perilaku seksual yang menyasar ke anus. ${ }^{9}$

7 Dalam realitanya, Islam bukanlah satu-satunya agama yang menentang praktik homoseksual. Dalam Injil telah tersemat ayat-ayat tentang homoseksualitas, baik dilakukan oleh sesama laki-laki maupun sesama perempuan.

Mereka berbuat seolah-olah mereka penuh nikmat, tetapi mereka telah menjadi jodoh. Mereka menggantikan kemuliaan Allah yang tidak fana dengan gambaran yang mirip dengan manusia yang fana, karena itu Allah menyerahkan mereka kepada keinginan hati mereka akan kecemaran, sehingga mereka saling mencemarkan tubuh mereka. Sebab mereka menggantikan kebenaran Allah dengan dusta dan memuja makhluk dengan melupakan penciptanya yang harus dipuji selama-lamanya, amin. Karena itu, Allah menyerahkan mereka kepada hawa nafsu yang memalukan (laki-laki dengan laki-laki dan perempaun dengan perempuan), sebab istri-istri mereka menggantikan persetubuhan yang wajar dengan yang tidak wajar. Begitu juga dengan suami-suami, meninggakan persetubuhanyang wajar dengan istri mereka dan menyala-nyala dalam birahi mereka seorang terhadap yang lain, sehingga mereka melakukan kemesuman. Laki-laki dengan laki-laki,..” (The Good News Bible, Roma 1:22-27; lihat juga Rama Azhari dan Putra Kencana, Membongkar Rahasia Jaringan Cinta Terlarang Kaum Homoseksual (Jakarta: Hujjah Press, 2008) hal.86).

8 Khulaipah Arroudho, "Epistemologi Penafsiran Olfa Youssef dalam Konstruksi Seksualitas Ayat-ayat al-Jinsiyyah al-Mitsliyyah”, dalam tesis UIN Sunan Kalijaga Yogyakarta, 2017, hal. 3-4.

9 Musdah Mulia, Mengupas Seksualitas: Mengerti Arti, Fungsi, dan Problematika Seksual Manusia Era Kita, Jakarta: Opus Prees, 2015, hal. 91-93. 
Selanjutnya dalam kajian ini, penulis memilih penafsiran Musdah Mulia sebagai objek kajian sebab Musdah Mulia merupakan salah satu tokoh dalam kajian pengembangan dan penafsiran Al-Qur'an yang cukup peka dan sensitif terhadap permasalahan seksualitas serta tanpa henti memperoduksi pemikiran yang kontroversi serta mengeksplorasi kontradiksi dalam kesimpulan-kesimpulannya tentang teks suci adalah Siti Musdah Mulia. Dia adalah perempuan pertama yang dikukuhkan LIPI sebagai Profesor riset bidang Lektur Keagamaan di Kementrian Agama (1999). Selain itu, karya-karyanya dikenal sangat kritis dan vokal menyuarakan nilai-nilai kemanusiaan berupa keadilan, demokrasi, pluralisme dan kesetaraan gender. Maka sangatlah wajar beberapa penghargaan nasional dan internasional diraihnya, salah satunya Women Of Courage Award dari Pemerintah Amerika Serikat (2007) atas kegigihannya dan memperjuangkan demokrasi dan HAM. ${ }^{10}$

Di samping itu, Siti Musdah Mulia sebagaimana dikutip oleh Masthuriah Sa'dan menjelaskan bahwa pengakuan HAM terhadap kaum LGBT (yang di dalamnya termsuk pelaku homoseksual) dimulai ketika APA (American Psychiatric Association) melakukan penelitian terhadap orientasi seksual homo. Hasil penelitian tersebut menyimpulkan bahwa homo dan orientasi seksual lainnya bukan abnormal, bukan penyimpangan psikologis dan juga bukan merupakan penyakit. Pasca penelitian tersebut, yakni pada tahun 1974 APA mencabut "homo" sebagai salah satu daftar dari penyakit jiwa. Bahkan, ketetapan ini diadopsi oleh Badan Internasional WHO dan diikuti oleh Departemen Kesehatan RI. pada tahun $1983 .{ }^{11}$ Tentu saja, penafsiran demikian merupakan penafsiran yang cukup berani, berlainan arus dengan kebanyakan mufassir atau pun para ulama, baik klasik maupun kontemporer.

Dengan demikian, tampaknya melakukan eksplorasi atau menemukan epistemologi penafsiran Musdah mulia tentang homoseksual dengan menganalisis karya-karya Musdah Mulia yang mengandung penafsiran tentang permasalahan homoseksual dari salah satu karyanya yang berjudul: Mengupas Seksualitas: Mengerti Arti, Fungsi, dan Problematika Seksual Manusia Era Kita menjadi kajian yang relatif menarik untuk ditindaklanjuti. Buku ini secara eksplisit memang bukanlah sebuah karya tafsir sebagaimana karya-karya tafsir yang padanya dinamakan bahwa ia adalah tafsir, sebut saja Tafsir Ibnu Katsir karya Ibnu Katsir, Tafsir Jalalain karya Jalaluddin as-Suyuthi dan Jalaluddin al-Mahalli, Tafsir alMishbah karya M. Quraish Shihab, Tafsir al-Azhar karya Hamka dan sebagainya, namun jika ditelisik lebih dalam dan kembali pada definisi tafsir sebagaimana

10 Musdah Mulia, Mengupas Seksualitas: Mengerti Arti, Fungsi, dan Problematika Seksual Manusia Era Kita, Jakarta: Opus Prees, 2015, hal. 233-235.

${ }^{11}$ Masthuriyah Sa'dan, Lgbt Dalam Perspektif Agama dan Ham, Jurnal Nizham, Vol. 05, No. 01 Januari-Juni 2016, hal. 22. 
dipaparkan oleh Muhammad Husain az-Zahabi ${ }^{12}$ bahwa tafsir adalah usaha manusia dalam menemukan maksud-maksud firman Allah Swt. sesuai dengan kemampuan manusia, yang meliputi segala upaya untuk memahami makna (teks) dan menjelaskan maksud (konteks). Maka buku ini dapat digolongkan sebagai sebuah penafsiran. Upaya penafsiran ini tampak dari bagaimana Musdah Mulia dalam bukunya - khususnya bab homoseksual - mencoba untuk memaparkan suatu ayat kemudian menafsirkannya dengan melihat segi sejarahnya, mengutip penafsiran ulama lain, menelitinya dari segi bahasa dan mengaitkannya dengan konteks sekarang ini. Dengan alasan demikian, menurut hemat penulis buku ini layak untuk disebut sebagai sebuah penafsiran.

Selanjutnya penelitian ini dimaksudkan sebagai upaya guna mengetahui bangunan penafsiran yang dilakukan oleh Musdah Mulia dalam karya tersebut, yakni dengan mengungkapkan sumber-sumber penafsiran, metode penafsiran, dan validitas penafsiran Musdah Mulia, sehingga akan lebih memperjelas arah penafsirannya.

\section{Epistemologi Tafsir}

\section{Pengertian epistemologi tafsir}

Istilah epistemologi berasal dari bahasa Yunani, episteme, yang berarti pengetahuan dan logos yang berarti ilmu. ${ }^{13}$ Dari akar kata ini epistemologi dimaksudkan sebagai teori pengetahuan. Yakni, pengkajian mengenai karakteristik pengetahuan, sumber, nilai, asal, struktur, metode-metode, kesahihan dan tujuan pengetahuan. ${ }^{14}$ Adapun term tafsir secara etimologi berasal dari kata al-fasru yang artinya menjelaskan dan mengupas makna. ${ }^{15}$ Sedangkan tafsir secara terminologi adalah ilmu yang membahas tentang penjelasan-penjelasan atau maksud-maksud

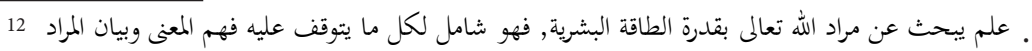

(Muhammad Husain az-Zahabi, at-Tafsir wa al-Mufassirun, juz 1, Kairo: Dar al-Hadis, 2005, hal. 19).

13 Aceng Rachmat dkk., Filsafat Ilmu Lanjutan, Jakarta: Kencana, 2011, hal. 147; lihat juga Biyanto, Filsafat Ilmu dan Ilmu Keislaman, Yogyakarta: Pustaka Pelajar, 2015, hal. 157; lihat juga Aksin Wijaya, Nalar Kritis Epistemologi Islam Membincang Dialog Kritis Para Kritikus Muslim: Al-Ghazali, Ibnu Rusyd, Thaha Husein, dan Muhammad Abid al-Jabiri Yogyakarta: Kalimeda, 2017, hal. 26.

${ }^{14}$ Listiyono Sntoso dkk., Epistemologi Kiri, Yogyakarta: Ar-Ruzz Media, 2003, hal. 52; lihat juga Nunu Burhanuddin, "Pemikiran Epistemologi Barat: dari Plato Sampai Gonseth", Jurnal Intizar, Vol. 21, No. 1, 2015, hal. 133; lihat juga Tim Dosen Filsafat Ilmu Fakultas Filsafat UGM, Filsafat Ilmu (Yogyakarta : Liberty, 1996), hal. 17.

${ }_{15}$ Mahmud Basuni Fawdah, Tafsir-tafsir Al-Qur'an: Perkenalan dengan Metodologi Tafsir terj. M. Mochtar Zoemi dan Abdul Qadir Hamid, Bandung: Pustaka, 1987, hal. 1; lihat juga Ahmad Musthafa Hadna, Problematika Menafsirkan Al-Qur'an, Semarang: Dina Utama Semarang, 1993, hal. 15; lihat juga Abd. Muid Nawawi, "Hermeneutika Tafsir Maudhu'i”, Jurnal Suhuf, Volume 9, Nomor 1, Juni 2016, hal. 3 . 
(firman) Allah Swt. sesuai dengan kemampuan manusia, yang meliputi segala upaya untuk memahami makna (teks) dan menjelaskan maksud (konteks). ${ }^{16}$

Berdasarkan paparan di atas, dapat disimpulkan bahwa epistemologi tafsir merupakan komparasi dua disiplin ilmu dengan aliran dan fokus kajian yang berbeda. Epistemologi tafsir yaitu mengupas seluk beluk pengetahuan tentang penjelasan dan penyingkapan makna dalam sebuah ayat dengan mengkaji secara khusus sumber-sumber, metode dan validitas suatu penafsiran.

\section{Komponen Epistemologi Tafsir}

Epistemologi tafsir mencakup tiga pembahasan, yaitu sumber, metode dan validitas tafsir. Pembahasan pertama adalah sumber ilmu pengetahuan dalam epistemologi, kemudian uraian tentang sumber dalam penfasiran sendiri.

Sumber pengetahuan merupakan cikal bakal terjadinya pengetahuan. ${ }^{17}$ Dalam tradisi filsafat barat berupa rasio/nalar (reason); pengalaman indera (sense experience). Sedangkan dalam khazanah pemikiran Islam, meliputi rasio/nalar (reason); intuisi (intuition); dan wahyu (revelation). ${ }^{18}$

Menurut Abdul Mustaqim, sumber penafsiran dalam tradisi penafsiran era kontemporer bersumber pada teks Al-Qur'an, akal (ijtihad) dan realitas empiris. Secara paradigmatik, posisi teks, akal, dan realitas ini berposisi sebagai objek dan sobjek sekaligus. Ketiganya selalu berdialektik secara dialogis triadic. ${ }^{19}$

Maka, dalam epistemologi tafsir ini yang menggabungkan tradisi keilmuan barat dengan tradisi Islam, dapat digunakan beberapa sumber untuk mendapatkan pengetahuan, ialah teks sebagai bagian dari wahyu, rasio, empiris dan intusi.

Sementara dalam tradisi penafsiran, sumber tafsir yang umum diketahui terbagi menjadi tiga; tafsīr bi al-Ma'tsūr, tafsìr bi ar-Ra'yi dan tafsīr bi al-Isyāri.

Komponen Epistemologi yang kedua yaitu metode atau cara memperoleh pengetahuan. Cara atau jalan yang dilalui oleh proses ilmu sehingga mencapai kebenaran adalah bermacam-macam, tergantung kepada sifat ilmu itu sendiri. ${ }^{20}$ Misalnya metode untuk menyusun ilmu pengetahuan, maka bagi Francis Bacon terdapat empat metode: Observasi (pengamatan), measuring (pengukuruan), exolaining (penjelasan), dan verifying (pemeriksaan benar tidaknya). ${ }^{21}$ hal. 19.

${ }^{16}$ Muhammad Husain az-Zahabi, at-Tafsir wa al-Mufassirun, juz 1, Kairo: Dar al-Hadis, 2005,

17 Surajiyo, Ilmu Filsafat Suatu Pengantar, Jakarta: PT Bumi Aksara, 2005, hal. 55.

18 A. Khudori Soleh, integrasi Agama \& Filsafat Pemikiran Epistimologi al-Farabi (Malang: UIN-MALIKI Press, 2010), hal. 85.

19 Abdul Mustaqim, Epistemologi Tafsir Kontemporer, Yogyakarta: LkiS Group, 2012, hal. 289.

${ }^{20}$ Endang Saifuddin Anshari, Ilmu Filsafat dan Agama, Surabaya: PT Bina Ilmu, 1982, hal. 61

${ }^{21}$ Endang Saifuddin Anshari, Ilmu Filsafat dan Agama, Surabaya: PT Bina Ilmu, 1982, hal. 61 
Dalam literatur yang lain juga disebutkan, bahwa di dalam tradisi epistemologi Islam, sumber-sumber pengetahuan itu diterapkan dengan metode yang berbeda. Jika ndra untuk metode bayani (observasi), akal untuk metode burhani (logis/demonstratif) dan hati untuk metode Irfani (intuitif). ${ }^{22}$

Sementara dalam bidang ilmu tafsir, metode yang digunakan secara umum dikenal empat macam metode penafsiran, yaitu metode tahlily/analisis, metode ijmaly/global, metode muqarin/perbandingan, dan metode maudhu'i/tematik.

\section{Sekilas Tentang Seks, Seksualitas dan Homoseksual}

\section{Arti Seks dan Seksualitas}

Istilah seks lebih banyak berkonsentrasi kepada aspek biologis seseorang, meliputi perbedaan komposisi kimia hormone dalam tubuh, anatomi fisik, reproduksi dan karakteristik biologis lainnya. Nasaruddin Umar memaparkan bahwa seks lebih ditekankan pada keadaan anatomis manusia yang kemudian memberi "identitas" kepada yang bersangkutan. Seseorang yang memiliki anatomi penis disebut laki-laki. Sedangkan orang yang memiliki anatomi vagina disebut perempuan. $^{23}$

Adapun seksualitas secara umum merupakan segala hal yang memiliki relasi dengan alat kelamin atau berkaitan dengan hubungan intim laki-laki dan perempuan. ${ }^{24}$ Demikian juga Kementrian Agama RI Badan Litbang dan Diklat Lajnah Pentashihan Mushaf Al-Qur'an (LPMA) menuliskan bahwa seksualitas dalam arti luas menyangkut segala sesuatu yang bersifat seksual. Aspek utama seksualitas adalah seks, seks biologi, gender, identitas gender, peran gender, dan orientasi seksual yaitu ketertarikan seseorang kepada orang lain. ${ }^{25}$

Demikian beberapa perbedaan yang paling mendasar antara seks dan seksualitas. Seks sebagaimana dipaparkan sebelumnya adalah sesuatu yang bersifat biologis dan karenanya seks dianggap sebagai sesuatu yang stabil. Seks biasanya merujuk pada alat kelamin dan tindakan penggunaan alat kelamin itu secara seksual. Meskipun seks dan seksualitas secara analisis merupakan istilah yang berbeda, namun istilah seks sering digunakan untuk menjelaskan keduanya.

\footnotetext{
${ }^{22}$ Abuddin Nata, Islam dan Ilmu Pengetahuan, Jakarta: Prenadamedia Group, 2018, hal. 186

${ }^{23}$ Nasaruddin Umar, Argumen Kesetaraan Gender Persepektif Al-Qur'an, Jakarta: Paramadina, 2001, hal. 35-36.

${ }^{24}$ Rudi Gunawan, filsafat Seks, Yogyakarta: Bentang, 1993, hal. 8.

${ }^{25}$ Kementrian Agama RI, Tafsir Ilmi: Seksualitas dalam Perspektif Al-Qur'an dan Sains, Jakarta: Lajnah Pentashihan Mushaf Al-Qur'an, 2012, hal. 1.
} 
Misalnya, seks juga digunakan sebagai istilah yang merujuk pada praktik seksual atau kebiasaan. ${ }^{26}$

Selanjutnya adalah uraian tentang permasalahan yang berkaitan dengan seksualitas yaitu orientasi seksual dan perilaku seksual yang keduanya merupakan implikasi spesifik yang tidak bisa dipisahkan. Orientasi seksual adalah kapasitas yang dimiliki setiap manusia berkaitan dengan ketertarikan emosi, rasa sayang, dan hubungan seksual. Orientasi seksual bersifat kodrati, tidak dapat diubah. Tak seorang pun dapat memilih untuk dilahirkan dengan orientasi seksual tertentu. $^{27}$

Adapun Jenis-jenis orientasi seksual ada tiga yaitu: a). Heteroseksual, aktivitas seksual dimana pasangan seksual yang dipilihnya berasal dari lawan jenis. b). Biseksual, aktivitas seksual dimana pasangan seksual yang dipilih berasa dari lawan jenis dan sesama jenis. c). Homoseksual, aktivitas seksual dimana pasangan seksual yang dipilih berasal dari sesama jenis. Pria homoseksual disebut gay dan perempuan homoseksual disebut lesbian. ${ }^{28}$ Namun, dalam literatur yang berbeda studi tentang orientasi seksual menyimpulkan ada beberapa varian orientasi seksual, yaitu heteroseksual (hetero), homoseksual (homo), biseksual (bisek), dan aseksual (asek), aseksual tidak tertarik pada keduanya, baik sesama maupun lawan jenis. ${ }^{29}$

Sedangkan perilaku seksual adalah cara seseorang mengekspresikan hubungan seksualnya. Perilaku seksual sangat dipengaruhi oleh nilai-nilai budaya, interpretasi agama, adat tradisi, dan kebiasaan masyarakat. Karena itu, perilaku seksual merupakan kontruksi seksual, tidak bersifat kodrati, dan tentu saja dapat dipelajari. Di sinilah menurut Husain Muhamad perbedaan mendasar antara orientasi seksual dan perilaku seksual. Sayangnya, tidak banyak orang yang mau memahami perbedaan kedua istilah ini secara arif. Akibatnya, tidak sedikit yang menemui keduanya secara rancu dan salah kaprah. ${ }^{30}$

${ }^{26}$ Husain Muhammad et al, Fiqih Seksualitas: Risalah Islam dalam Pemenuhan Hak-Hak Seksual, t.tp.: PKBI, t.t., hal. 11.

${ }^{27}$ Husain Muhammad et al, Fiqih Seksualitas: Risalah Islam dalam Pemenuhan Hak-Hak Seksual, t.tp.: PKBI, t.t., hal. 16.

${ }^{28}$ Yurni, “Gambaran Perilaku Seksual dan Orientasi Seksual Mahasiswa di Kota Jambi” Jurnal Ilmiah Dikdaya, hal. 89).

${ }^{29}$ Husain Muhammad et al, Fiqih Seksualitas: Risalah Islam dalam Pemenuhan Hak-Hak Seksual, t.tp.: PKBI, t.t., hal. 11 .

${ }^{30}$ Husain Muhammad et al, Fiqih Seksualitas: Risalah Islam dalam Pemenuhan Hak-Hak Seksual, t.tp.: PKBI, t.t., hal. 20. 


\section{Homoseksual Sebagai Perilaku dan Orientasi Seksual}

Secara etimologi, homoseksual berasal dari bahasa Yunani, 'homoios' 'homo's1, ' $\operatorname{homos}^{32}$ ' yang artinya "sama”, dan bahasa Latin 'sexus' berarti jenis kelamin. ${ }^{33}$ Adapun secara terminologi, homoseksual merupakan ketertarikan secara seksual pada jenis kelamin yang sama, perempuan tertarik pada perempuan yang disebut sebagai lesbian, dan laki-laki yang tertarik pada laki-laki disebut sebagai gay. ${ }^{34}$

Perilaku seksual atau cara melampiaskan hasrat seksualnya ini dilakukan dengan cara memasukkan zakar ke dalam dubur, sedangkan lesbian dilakukan dengan cara masturbasi satu sama lain, atau cara lainnya, untuk mencapai orgasme (climax of the sex act) ${ }^{35}$. Cara yang lain adalah dengan memanipulasi alat kelamin pasangannya dengan memasukan penis dalam mulut (oral erotisme), dengan menggunakan bibir (fellatio;menghisap), dan lidah (cunnilingus; menjilat).

Maka dapat disimpulkan bahwa homoseksual merupakan kecederungan parasaan, emosional, dan hasrat seksual kepada sesama jenis, dengan segala bentuk pelampiasan nafsu baik melalui mulut, anus, paha dan sebagainya. Selain itu, perlu ditegaskan kembali tentang relasi homoseksual dengan perilaku dan orientasi seksual, bahwa orientasi seksual tidak selalu paralel atau sejajar dengan perilaku seksual. Artinya, seseorang yang memiliki orientasi homoseksual belum tentu berperilaku homoseks dengan segala bentuk perbuatannya, demikian juga orang yang berperilaku homoseks misal sodomi memiliki orientasi homoseksual, bisa jadi dia heteroseksual atau biseksual. Dengan kata lain, orang yang homo belum tentu sodomi dan yang sodomi belum tentu homo.

\section{Penafsiran Musdah Mulia tentang Ayat Ayat Homoseksual}

Pembahasan homoseksual selalu dinisbatkan pada kisah Nabi Luth dalam Al-Qur'an. Oleh sebab itu, homoseksual dalam istilah arab disebut sebagai liwath yang merupakan representasi dari perbuatan kaum Nabi Luth. Berdasarkan pada

${ }^{31}$ Rama Azhari dan Putra Kencana, Membongkar Rahasia Jaringan Cinta Terlarang Kaum Homoseksua, Jakarta: Hujjah Press, 2008, hal. 24.

32 Elga Andina, "Faktor Psikologi dalam Interaksi Masyarakat dengn Gerakan LGBT di Indonesia”, Jurnal Aspirasi, Vol.7 No. 2, Desember 2016, hal. 175.

33 Tommy Dwi Pranata, "Perilaku dan Realitas Sosial Kehidupan Gay di Kota Samarinda", eJournal Sosiatri-Sosiologi, Vol. 3, 2015, 140. atau 'sex' yang berarti 'seks'; lihat juga: Rama Azhari dan Putra Kencana, Membongkar Rahasia Jaringan Cinta Terlarang Kaum Homoseksual, Jakarta: Hujjah Press, 2008, hal. 24.

${ }^{34}$ Ratri Endah Mastuti, Rachmad Djati Winarno, Lita Widyo Hastuti “Pembentukan Identitas Orientasi Seksual pada Remaja Gay" Jurnal Prediksi, Kajian Ilmiah Psikologi - No. 2, Vol . 1, Juli - Desember 2012, hal. 194 - 197

${ }^{35}$ Agus Salim Nst, "Homoseksual dalam Pandangan Hukum Islam”, Jurnal Ushuluddin Vol. XXI No. 1, Januari 2014, hal. 24. 
penelusuran atau penelitian yang dilakukan oleh Muhammad Fuad 'Abdul Baqi dalam kitab Mu'jam al-Mufahras, kata Luth atau pembahasan yang mengarah pada sosok Nabi Luth (sesuai dengan yang disebutkan penulis) kurang lebih tercatat sebanyak 27 ayat dari 14 surat dalam Al-Qur'an, yaitu: QS. Al-An'am [6]: 86; QS. Al-A'raf [7]: 80;QS. Hud [11]: 70, 74, 77, 81, 89; QS. Al-Hijr [15]: 59, 61; QS. Al-Anbiya' [21]: 71, 74; QS. Al-Hajj [22]: 43; QS. Al-Syu'ara' [26]: 160, 161, 167; QS. An-Naml [27]: 56; QS. Al-Ankabut [29]: 26; QS. As-Shaffat [37]: 133; QS. Shad [38]: 13; QS. Qaf [50]: 13; QS. Al-Qamar [54]: 33-34; dan QS. AtTahrim [66]: 10. ${ }^{36} \mathrm{Hal}$ tersebut senada pula dengan penelitian yang diakukan oleh Ali Audah dalam karyanya "Konkordansi Qur'an"37, Muhammad 'Audhal 'Aidi dalam kitab Al-Fihrisu Al-Maudhu'i li Al-Ayati Al-Qur'an Al-Karimi, ${ }^{38}$ dan Dr. Husain Muhammad Fahmi as-Syafi'i dalam kitab Ad-Dalil Al-Mufahras li Al-Fadzi Al-Qur'an Al-Karimi. ${ }^{39}$

Namun setelah penulis telusuri lebih dalam tentang ayat-ayat yang membahas tentang Rasul yang ke 7 tersebut, dengan melihat beberapa literatur yang ada, ternyata tidak semua ayat tersebut berkenaan dengan penyimpangan seksual. Abdul Mustaqim menyebutkan hubungan seksual sesama jenis, yang Al-Qur'an menyebutnya sebagai perbuatan fahisyah (keji) dan israf (berlebihan) terdapat dalam QS. Al-A'raf: 80-84, Asy-Syu'ara', 23: 160-175; Al-Hijr, 15: 61-77; An-Naml, 27: 56). ${ }^{40}$ Sedangkan menurut Musdah Mulia ayat-ayat yang menjadi dasar penolakan pada praktik homoseksual terdapat dalam QS. An-Naml, 27: 54-58. Hud, 11: 77-83; Al-A'raf,7: 80-81; Al-Syu'ara, 26: 160-175; al-Anbiya', 21: 74; dan an-Ankabut, 29: 29. ${ }^{41}$ Dari kedua pendapat tersebut, terlihat di sana ada persamaan dan perbedaan dalam pengambilan surat dan ayat yang membahas tentang homoseksual yang dinisbatkan pada kisah Nabi Luth. Abdul Mustaqim menyebutkan 4 surat dan Musdah Mulia 6 surat. Persamaan surat yang diambil yaitu surat As-Syuara', Al-Naml, dan Al-A'raf. Meskipun sama dalam penyebutan

${ }^{36}$ Muhammad Fuad 'Abdul Baqi, “Al-Mu'jam Al-Mufahras Li Alfadz Al-Qur'an Al-Karimi, Kairo: Dar al-Hadis, 2001, hal. 852-853. Lihat juga: Ibrahim Al-Abyari, Al-Mausu'ah Al-Qur'aniyyah, Kairo: Dar Al-Kitab Al-Misri, 1984, vol, 7, hal. 507.

${ }^{37}$ Ali Audah, Korkondansi Qur'an: Panduan Kata dalam Ayat Qur'an Cet. 4, Bogor: Pustaka Litera Antar Nusa, 2008, hal.392.

${ }^{38}$ Muhammad 'Audhal 'Aidi, Al-Fihrisu Al-Maudhu'i li Al-Ayati Al-Qur'an Al-Karimi, Kairo: Markaz al-Kitaba li An-Nasyri, 2004, juz, 3 hal. 1952-1953

${ }^{39}$ Husain Muhammad Fahmi as-Syafi'i, Ad-Dalil Al-Mufahras li Al-Fadzi Al-Qur'an Al-Karimi, Kairo: Dar as-Salam, 2008, hal. 84.

${ }^{40}$ Abdul Mustaqim, "Homoseksual Dalam Perspektif Al-Qur’an: Pendekatan Tafsir Kontekstual al-Maqashidi,” Jurnal Suhuf, Vol.9, No.1, Juni 2016, hal. 51.

${ }^{41}$ Musdah Mulia, Mengupas Seksualitas: Mengerti Arti, Fungsi, dan Problematika Seksual Manusia Era Kita, Jakarta: Opus Prees, 2015, hal. 95. 
ketiga surat ini, namun keduanya berbeda pula dalam penyebutan ayatnya. Kendati berbeda, menurut hemat penulis maksud yang dituju adalah sama.

Selanjutnya untuk memudahkan pembahasan terkait paradigma Musdah Mulia tentang homoseksual, di sini penulis mencoba untuk memetakannya menjadi tiga pembahasan, yaitu: homoseksual berbeda dengan liwath kaum Nabi Luth., biseksual sebagai orientasi seksual kaum Nabi Luth, perilaku kaum luth bersifat global dan azdab sebagai hak priogratif Tuhan.

\section{Homoseksual Berbeda dengan Liwath Kaum Nabi Luth}

Dalam kitab-kitab fikih istilah homoseksualitas sering diartikan sama dengan sodomi (perilaku seksual dengan memasukkan penis ke dalam anus). Jika yang dikutuk dalam fikih (seperti Imam al-Auza'i dan Abu Yusuf yang menyamakan hukuman sodomi dengan zina) adalah perilaku seksual dalam bentuk sodomi, maka itu tidak ada kaitannya dengan orientasi seksual seseorang. Sebab, sodomi bukan hanya dilakukan oleh kelompok homoseksual melainkan juga kelompok heteroseksual. Demikian sebaliknya, tidak sedikit kelompok homoseksual yang anti sodomi, bahkan mereka anti pada semua bentuk penetrasi penis. Mereka hanya melakukan perilaku seksual tanpa menggunakan alat kelamin, seperti ciuman, pelukan, dan sebagainya. ${ }^{42}$

Uraian singkat di atas menggambarkan bahwa homoseksual sesungguhnya bukanlah "liwath" atau "luthi", kedua istilah ini merujuk pada relasi seksual yang pernah dilakukan kaum Luth as. yang kemudian kaum tersebut dikenal dengan kaum sodom, yang pada akhirnya dalam Islam istilah "sodom" disamakan dengan "liwath". Bahkan, kota atau tempat tinggal Nabi Luth as. Dinisbatkan pada perilaku kaum itu sendiri, yakni "liwath" (luthy secara literal berarti kaum Nabi Luth). Namun yang menjadi permasalahan dan tidak dibenarkan adalah ketika istilah "luthiy" sering digunakan sebagai ungkapan penghinaan yang sangat merendahkan bagi kaum homoseksual. Bahasan ini dapat dipahami pada ayat dalam Al-Qur'an,

"Dan (Kami juga telah mengutus) Luth (kepada kaumnya). (Ingatlah) tatkala dia berkata kepada mereka: "Mengapa kamu mengerjakan perbuatan faahisyah itu, yang belum pernah dikerjakan oleh seorangpun (di dunia ini) sebelummu? Sesungguhnya kamu mendatangi lelaki untuk melepaskan nafsumu (kepada

${ }^{42}$ Musdah Mulia, Mengupas Seksualitas: Mengerti Arti, Fungsi, dan Problematika Seksual Manusia Era Kit, Jakarta: Opus Prees, 2015, hal. 90-91. Lihat juga : Abdullah Nashih Ulwan, Hassan Hathout, Pendidikan Anak Menurut Islam Pendidikan Seks, terj. Khalilullah Ahmas Masjkur Hakim dan Jalaludin Rahmat, Bandung: PT Rosdakarya, 1992, hal. 151. 
mereka), bukan kepada wanita, malah kamu ini adalah kaum yang melampaui batas." (Q.S. al-A'raf [7]: 80-81)

Perkataan Nabi Luth kepada kaumnya di atas dijabarkan oleh Musdah Mulia sebagaimana mengutip at-Thabari, ialah:

$$
\text { ايها القوم اتأتون الرجال في ادبارهم شهوة منكم لذالك من دون الذي اباحه الله لكم واحله من النساء }
$$

Kalian telah melakukan hubungan seks secara keji dengan laki-laki melalui anus mereka dan bukannya dengan perempuan sebagaimana yang dihalalkan Allah.

Musdah Mulia menjelaskan bahwa melalui paparan Imam at-Thabari ini menunjukkan dengan jelas sesungguhnya "liwath" atau "luthi" merupakan apa yang lazimnya dikenal dengan istilah "sodom". Dengan demikian, dapatlah dikatakan bahwa homoseksual tidaklah sama dengan liwath. Homoseksual merupakan orientasi seksual kepada sesama jenis, sementara liwath (sodomi) adalah perilaku seksual yang menyasar ke anus, bukan ke vagina. Karena itu, tidak sepatutnya para pelaku homoseksual diperlakukan sama dengan pelaku sodomi, baik secara sosial maupun hukum. ${ }^{43}$

Selain itu, Musdah Mulia juga memaparkan bahwa di dalam Al-Qur'an tidak ada kalimat yang secara tegas mengatakan kalimat liwath atau sodomi. Sebagaimana dalam perkataan yang ditulis dalam karyanya,

"salah satu bentuk pelanggaran yang spesifik dilakukan kaum Luth adalah mengekspresikan perilaku seksual terlarang; mengandung unsur kekerasan, pemaksaan dan penganiayaan, di antaranya dalam bentuk sodomi yang keji. Akan tetapi, Al-Qur'an dan hadis tidak menggunakan kosa kata yang secara langsung dapat diartikan dengan liwath atau sodomi" ${ }^{44}$

Dari pemaparan di atas dapat disimpulkan bahwa luthi atau liwath adalah sodomi, bukan homoseksual. Maka homoseksual berbeda dengan liwath atau sodomi. Homoseksual adalah orientasi seksual yang merupakan refleksi dari unsur kasih sayang pada diri seseorang. Sedangkan sodomi atau liwath adalah perilaku seksual yang merupakan refleksi dari hasrat biologis. Orang yang homoseksual belum tentu melakukan sodomi demikian juga orang yang melakukan sodomi belum tentu homoseksual karena bisa jadi ia melakukannya untuk perempuan.

${ }^{43}$ Musdah Mulia, Mengupas Seksualitas: Mengerti Arti, Fungsi, dan Problematika Seksual Manusia Era Kit, Jakarta: Opus Prees, 2015, hal. 91-93.

${ }_{44}$ Musdah Mulia, Mengupas Seksualitas: Mengerti Arti, Fungsi, dan Problematika Seksual Manusia Era Kit, Jakarta: Opus Prees, 2015, hal. 95-96.. 


\section{Perilaku Buruk Kaum Luth Bersifat Global}

Permasalahan homoseksual selain mengacu secara spesifik pada kata liwath, dalam Al-Qur'an yang juga mengandung konteks kisah Nabi Luth as. menyebutkan beberapa istilah sebagai label perbuatan itu, seperti al-fahisyah, al-sayyiat, al-khabaits dan al-munkar. Berdasarkan hasil pemetaan ayat yang dilakukan oleh Jules La Beaume, telah ditemukan bahwa empat istilah tersebut termktub dalam 6 ayat dari 5 surat, ialah al-fahisyah (QS. Al-A'raf [7]: 80; QS. AnNaml [27]: 54, QS. Al-Ankabut [29]: 28) al-sayyiat, (QS. Hud [11]:78), al-khabaits, (QS. Al-Anbiya' [21]: 74), dan al-munkar (QS. Al-Ankabut [29]: 29) ${ }^{45}$

Menyikapi tentang ayat-ayat yang mencakup empat istilah dalam konteks kisah Nabi Luth tersebut, Musdah Mulia menafsirkan bahwa istilah al-fahisyah, al-sayyiat, al-khabaits dan al-munkar itu bersifat umum bukan hanya mengarah pada perilaku homoseksual tetapi juga heteroseksual. Sebagaimana dalam ungkapannya,

“empat istilah kejahatan yang disebutkan dalam Al-Qur'an itu bersifat umum, bukan hanya dilakukan oleh kelompok homo, melainkan juga kelompok hetero, bisek dan aseksual. Dengan ungkapan lain, semua manusia tanpa membedakan kelompok heteroseksual, sangat mungkin dan bisa terlibat dalam berbagai bentuk kejahatan seksual (sex crime) yang diistilahkan dalam empat ungkapan Al-Qur'an tersebut." 46

Dengan demikian, memahami apa yang disampaikan Musdah Mulia bahwa konteks ayat yang menjadi sifat bagi perbuatan kaum Nabi Luth as. tidak mengarah pada perilaku homoseksual saja. Hal tersebut dapat dipahami dengan penggunaan kalimat yang sebagian berbentuk jamak (banyak) dan sebagian lainnya berbentuk mufrad (satu). Oleh sebab itu, untuk mengetahui lebih jelas perihal tafsiran istilah tersebut, mari perhatikan beberapa tafsiran dari mufassir lainnya.

Setiap perbuatan jahat adalah munkar. Adapun contoh perbuatan munkar ialah seperti yang dilakukan oleh kaum Nabi Luth as. Hal ini sebagaimana disebutkan dalam (QS. Al-Ankabut [29]: 29) yakni "perbuatan keji dan munkar". Dan nampak ada yang lebih buruk dari perbuatan yang munkar, ialah perbuatan yang keji (fahisya', fahsya'). Perbuatan tersebut adalah. Laki-laki yang mendatangi

\footnotetext{
${ }^{45}$ Jules La Beaume, Tafsil Ayati Al-Qur'an Al-Hakim, terj. Muhammad Fuad 'Abdul Baqi, Mesir: Dar al-wahyi al-Muhammadi, 644, hal. 113-116.

${ }^{46}$ Musdah Mulia, Mengupas Seksualitas: Mengerti Arti, Fungsi, dan Problematika Seksual Manusia Era Kit, Jakarta: Opus Prees, 2015, hal. 97.
} 
laki-laki atau homoseksualitas. Di kalangan perempuan, perbuatan itu disebut lesbian. ${ }^{47}$

Terkait dengan perbuatan yang tidak mengandung unsur seksualitas, tentu pelaku perbuatan tersebut berlaku umum, yakni bisa dilakukan oleh siapa saja, tak mengenal jenis kelamin ataupun orientasi seksual. Hal ini sebagaimana dipertegas oleh Musdah Mulia dalam tafsirnya di atas. Sedangkan terkait hal yang mengandung seksualitas, Musdah Mulia menyatakan jika keempat istilah tersebut diartikan sebagai sodomi - dalam arti liwath, bukan homoseksual. Oleh sebab itu, perbuatan sodomi tersebut tidak hanya dilakukan oleh kamu homo, yakni laki-laki yang mempunyai kecenderungan orientasi seksual dengan laki-laki, namun hal tersebut juga bisa dilakukan oleh kaum heteroseksual kepada istrinya. Dalam arti luas, apapun orientasi seksualnya, mereka sangat mungkin untuk melakukan kejahatan seksual. Dan yang dikecam dalam ayat tersebut adalah perbuatan sodomi bukan homoseksual (dalam ranah orientasi seksual).

\section{Biseksual Sebagai Orientasi Seksual Kaum Luth}

Biseksual adalah seseorang baik laki-laki maupun perempuan yang mempunyai ketertarikan seksual terhadap laki-laki sekaligus perempuan dalam waktu yang bersamaan..$^{48}$ Kemudian, berkaitan dengan ayat-ayat yang menyebutkan tentang perilaku kaum Nabi Luth as. sebagaimana telah disebutkan pada bahasan sebelumnya, Musdah Mulia mengungkapkan bahwa kaum Nabi Luth as. mengindikasikan sebagai pelaku biseksual. ${ }^{49}$

Jadi menurut Musdah Mulia, sebagian besar kaum Nabi Luth as. melakukan kekerasan dan pemaksaan, khususnya terkait kejahatan seksualitas, sehingga merugikan dan mencederai orang lain. Bahkan mereka berpaling dari istrinya dan mendatangi tamu Nabi Luth untuk melakukan perilaku yang keji seperti yang digambarkan Al-Qur'an (QS. As-Syu'ara' [26]:165-166). ${ }^{50}$ Dengan demikian,

${ }^{47}$ M. Dawam Rahardjo, Ensiklopedi Al-Qur'an: Tafsir Sosial Berdasarkan Konsep-konsep kunci, cet, II, Jakarta: Paramadina, 2002, hal. 636.

${ }^{48}$ Rohmawati, "Perkawinan Lesbian, Gay, Biseksualdan Transgender/Transeksual (Lgbt) Perspektif Hukum Islam” Jurnal Ahkam, Volume 4, Nomor 2, November 2016, hal. 310.

${ }^{49}$ Musdah Mulia, Mengupas Seksualitas: Mengerti Arti, Fungsi, dan Problematika Seksual Manusia Era Kit, Jakarta: Opus Prees, 2015, hal. 97.

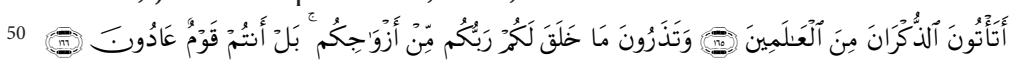

Mengapa kamu mendatangi jenis lelaki di antara manusia, dan kamu tinggalkan isteri-isteri yang dijadikan oleh Tuhanmu untukmu, bahkan kamu adalah orang-orang yang melampaui batas". Lihat: Ira D. Aini, Mujahidah Muslimah: Kiprah dan Pemikiran Prof. Dr. Siti Musdah Mulia, M.A,. Bandung: Nuansa Cendekia, 2013, hal. 199-200. 
dengan sikap keberpalingan mereka dari istri-istrinya menunjukan adanya orientasi biseksual (kecederungan pada jenis kelamin laki-laki juga perempuan).

Kemudian bila ditelusuri lebih dalam ternyata ada kemungkinan apa yang paparkan Musdah Mulia itu tepat, karena jauh sebelum kaum Nabi Luth melakukan hubungan melalui dubur (sodomi) kepada sesama jenis, mereka melakukannya terlebih dahulu kepada istrinya lalu kemudian berubah ketertarikannya kepada sesama jenis. Hal ini telah dijelaskan oleh Al-Alusi yang bersumber dari riwayat Ibn Abi Dunya, dari Tawus dalam tafsirnya Ruh ala-Ma'ani, sebagaimana kalimat yang ditulisnya ialah,

$$
\text { وجاء في رواية ابن ابي الدنياعن طاوس ان قوم إنما أتوا أولا النساء في أدبارهن ثم أتوا الرجال }
$$

Sebuah riwayat dari Ibn Abi Dunya dari Tawus sesungguhnya kaum Nabi Luth as. telah menyetubuhi istri-istri mereka melalui dubur atau anusnya (sodomi) kemudian berubah menggauli sesama jenisnya dengan cara yang sama.

Bahkan dalam riwayat yang lain dikatakan mereka telah melakukan peraktik sodomi kepada istri-istrinya selama 40 tahun sebelum bergaul sesama lelakinya. Berikut kutipan kalimat yang ditulis as-Suythi dalam tafsirnya ad-Durr al-Mansur.

$$
\text { كان اللواط في قوم لوط في النساء قبل ان يكون في الرجال باربعين سنة } 52
$$

Kaum Luth telah melakukan liwath (sodomi) kepada istri-istrinya sebelum mereka melakukan kepada para lelaki selama 40 tahun.

Terkait penafsiran kali ini, belum ada penafsiran yang merespon terkait orientasi seksual kaum luth, sehingga belum ditemukan satu penafsiranpun yang merespon tafsiran ini.

\section{Azab Sebagai Hak Prerogratif Tuhan}

Keberadaan kaum homoseksual senantiasa dikaitkan dengan contoh historis kisah perilaku umat Luth. Dikemukakan bahwa Tuhan sangat murka terhadap kaum Nabi Luth yang berperilaku homoseksual. Kemurkaan Tuhan itu diwujudkan dengan menurunkan hujan batu dari langit dan membalikkan

${ }^{51}$ Al-Alusi, Ruh Al-Ma'ani fi Tafsiri Al-Qur'an al-'adzim wa al-Sab'i al-Matsani, Bairut: Dar Ihya' aliTurats al-'Arabi, 1985, juz 7, hal. 170.

${ }^{52}$ As-Suyuthi, ad-Durru al-Mantsur fi al-Tafsiri al-mantsur, Bairut: Dar al-Kutub al 'Ilmiyah, 1990, juz 3, hal. 185. 
bumi. Akhirnya kaum Luth hancur lebur, termsuk istrinya, kecuali pengikut yang beriman pada Luth. ${ }^{53}$

Berkaitan dengan Azab tersebut secara tekstual telah ada di dalam Al-Qur'an yang megisyaratkan terkait bencana alam berupa hujan batu yang diturunkan kepada kaum Nabi Luth yang durhaka. Sebagaimana yang ditemukan dalam kitab Tafshil Ayati Al-Qur'an Al-Hakim; yang mengelompakan ayat-ayat dalam Al-Qur'an, bahwa ada 5 ayat di 5 surat yang berbeda yang redaksi ayatnya menunjukkan turunnya azab hujan batu. Yaitu, (QS. Al-A'raf [7]: 83; Hud [11]: 82; Al-Hijr [15:74; An-Naml [17]: 58; As-Syu'ara' [26:173). ${ }^{54}$ Sederhananya, secara tekstual ayat-ayat tersebut menjadi bukti kuat akan adanya azab yang menimpa pelaku penyimpangan seksual yang dilakukan oleh kaum Nabi Luth as.

Musdah Mulia menafsirkan terkait kontekstualias makna azab yang menimpa kaum Nabi Luth as. bahwa azab pedih dalam cerita Luth juga ditimpakan pada umat nabi-nabi lainnya. Bahkan, azab bagi umat Nuh jauh lebih dahsyat sehingga peristiwa itu disebut kiamat pertama. Artinya, Allah selalu murka kepada setiap umat yang berbuat keji dan dzalim serta melampui batas, tidak peduli dengan orientasi seksual dan identitas gender mereka. Azab Allah tidak mesti berkaitan dengan soal seksulitas. Azab Allah dapat mengenai siapa saja, tidak membedakan homo atau hetero. ${ }^{55}$ Bukti lainnya, Musdah Mulia berpatokan pada azab yang menimpa istri Nabi Luth as. dimana menurutnya tidak ada informasi dalam Al-Qur'an yang menunjukkan bahwa ia lesbian atau melakukan sodomi. ${ }^{56}$ Sehingga, Musdah Mulia menyimpulkan, bahwa hanya Allah yang Mahatahu siapa dari umat manusia yang akan menerima azab-Nya dan siapa yang akan mendapatkan rahmat-Nya. Berlandaskan pada ayat Al-Qur'an (QS. Al-Ankabut [29]:21) ${ }^{57}$.

Dari pernyataan di atas, dapat disimpulkan bahwa azab yang menimpa kaum Luth tidak disebabkan oleh perbuatan sodomi semata, namun juga karena perbuatan keji lainnya, seperti merampok, mendustakan utusan Allah, dan perbuatan keji lainnya. Menurut hemat penulis, praktik penyimpangan seksual

${ }^{53}$ Rohmawati, "Perkawinan Lesbian, Gay, Biseksualdan Transgender/Transeksual (Lgbt) Perspektif Hukum Islam" Jurnal Ahkam, Volume 4, Nomor 2, November 2016, hal. 314.

${ }^{54}$ Jules La Beaume, Tafsil Ayati Al-Qur'an Al-Hakim, terj. Muhammad Fuad 'Abdul Baqi, Mesir: Dar al-wahyi al-Muhammadi, 644, hal. 113-116.

${ }_{55}$ Musdah Mulia, Mengupas Seksualitas: Mengerti Arti, Fungsi, dan Problematika Seksual Manusia Era Kit, Jakarta: Opus Prees, 2015, hal. 96.

${ }^{56}$ Musdah Mulia, Mengupas Seksualitas: Mengerti Arti, Fungsi, dan Problematika Seksual Manusia Era Kit, Jakarta: Opus Prees, 2015, hal. 96.

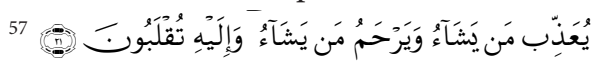

Allah mengazab siapa yang dikehendaki-Nya, dan memberi rahmat kepada siapa yang dikehendaki-Nya, dan hanya kepada-Nya-lah kamu akan dikembalikan. Lihat: Musdah Mulia, Mengupas Seksualitas: Mengerti Arti, Fungsi, dan Problematika Seksual Manusia Era Kita (Jakarta: Opus Prees, 2015), hal. 96. 
menjadi pemicu timbulnya keburukan yang lain. Artinya, hasrat seksual mereka yang besar membuat sikap mereka lebih buruk mulai dari keangkuhan dan sikap menentangnya pada ajaran Nabi Luth as. Mereka menolak ajakan pada kebaikan dan bahkan mereka marah ketika ditegur bahwa perbuatan homoseksual itu tidak dibenarkan. Dengan demikian, azab yang menimpanya bukan hanya tertuju pada penyimpangan seksual semata tetapi seluruh bentuk kedurhakaan yang kerap mereka lakukan.

\section{Kontruksi Epistemologis Penafsiran Musdah Mulia Terhadap Ayat-Ayat Homoseksual}

\section{Sumber Penafsiran Musdah Mulia tentang Homoseksual}

Sesuai dengan penelusuran yang telah dilakukan, penulis berpendapat bahwa sumber penafsiran Musdah Mulia terhadap ayat-ayat homoseksual adalah sumber tafsir bi al-ra'yi, yaitu pikiran atau nalar. Selanjutnya, guna mempermudah pembaca dalam menemukan sumber-sumber tersebut, penulis akan memaparkan sumber dalam beberapa point.

a. Teks Sebagai Sumber Penafsiran

Penafsiran Musdah menggunakan ayat Al-Qur'an dapat dilihat ketika Musdah berbicara tentang balasan yang diberikan kepada kaum homoseksual. Musdah menjelaskan bahwasannya hanya Allah yang Maha Tahu tentang siapa dari umat manusia yang akan menerima azab-Nya dan siapa yang akan mendapatkan rahmat dan karunia-Nya. Hal ini sebagaimana dipahami dalam Al-Qur'an Surat al-Ankabut [29] ayat 21.

Ayat Al-Qur'an yang digunakan Musdah Mulia adalah sebagai penguat dan penegasan atas penafsiran yang ada. Bahwasannya terkait perbuatan yang dilakukan manusia, baik berupa kebaikan dan kejahatan, hanya Allahlah yang berhak menetukan pahala dan azab baginya. Hal tersebut terlepas dari ikatan aliran tertentu karena semua ulama telah menyepakatinya bahwa tidak ada kuasa bagi manusia dalam memberikan kehendak karena manusia hanya dalam batas berusaha.

Sumber teks kedua dalam penafsiran Musdah adalah hadis Nabi Saw. Posisi hadis di sini sebagai penguat dan pendukung pemikirannya terkhusus dalam pembahasan homoseksual ini. Contohnya yaitu ketika Musdah menyebutkan beberapa hadis yang berbicara tentang penolakan terhadap homoseksual sebagaimana ungkapannya:

Secara teologis, penolakan terhadap homoseksual dinisbahkan pada ayat-ayat Al-Qur'an yang berkisah tentang Nabi Luth a.s. Di samping 
sejumlah ayat-ayat Al-Qur'an tersebut, ditemukan juga sejumlah hadis Nabi. Di antaranya, hadis riwayat Tabrani dan al-Baihaqi; Ibnu Abbas; Ahmad, Abu Dawud, Muslim dan Tirmidzi. ${ }^{58}$

Dalam penafsirannya yang lain, Musdah tidak menyebutkan periwayat hadis maupun bunyi hadis, namun secara tersirat dalam penafsirannya dapat diketahui bahwasannya ia juga merujuk hadis bahkan sebelum ia menafsirkan. Hal ini dapat diketahui dalam ungkapannya:

Salah satu bentuk pelanggaran yang spesifik dilakukan kaum Luth adalah mengekspresikan perilaku seksual terlarang; mengandung unsur kekerasan, pemaksaan dan penganiayaan, di antaranya dalam bentuk sodomi yang keji. Akan tetapi, Al-Qur'an dan hadis tidak menggunakan kosa kata yang secara langsung dapat diartikan dengan liwath atau sodomi. ${ }^{59}$

Selain Al-Qur'an dan hadis, Musdah juga merujuk pada penafsiran Mufassir sebelumnya. Contohnya yaitu penafsiran al-Thabari tehadap AlQur'an Surat al-A'raf ayat 80-81:

"Kalian telah melakukan hubungan seks secara keji dengan laki-laki melalui anus mereka, dan bukannya dengan perempuan sebagaimana yang dihalalkan Allah."

Dalam penafsirannya terhadap ayat-ayat homoseksual, Musdah tidak banyak mengutip pendapat para mufassir sebelumnya, al-Thabari merupakan satu-satunya mufassir terdahulu yang dikutip oleh Musdah. Adapun posisi penafsiran al-Thabari ini adalah sebagai penguat atas pemikirannya. Namun demikian, tidak semua pandangan mufassir terdahulu mutlak diikuti oleh Musdah. ${ }^{60}$

b. Rasio

Adapun peran akal dalam penafsiran menurut Musdah yaitu mengkonfirmasi apa yang dijelaskan oleh ayat Al-Qur'an. Secara operasional, setiap ayat AlQur'an harus dibaca secara kritis kemudian menghubungkan maknanya dengan ayat-ayat yang relevan dalam isu yang sama, semacam tafsir maudhu'i- hal ini penting dilakukan untuk menggali makna holistik dari sebuah ayat. Sebab seringkali kita belum dapat memahami konten satu ayat tanpa melihatnya dalam konteks yang luas. Oleh karena itu, jangan buru-buru menyimpulkan sesuatu hanya berlandaskan satu ayat, apalagi

\footnotetext{
${ }^{58}$ Musdah Mulia, Mengupas Seksualitas: Mengerti Arti, Fungsi, dan Problematika Seksual Manusia Era Kita, Jakarta: Opus Press, 2015, hal. 95.

59 Musdah Mulia, Mengupas Seksualitas: Mengerti Arti, Fungsi, dan Problematika Seksual Manusia Era Kita, Jakarta: Opus Press, 2015, hal. 96.

${ }^{60}$ Hasil wawancara dengan Musdah Mulia, pada tanggal 27 Januari 2018.
} 
sepotong atau setengah ayat - kemudian melakukan sintesa, komparasi antara satu ayat dengan ayat lainnya, menghubungkannya dengan konteks sosio-politik pada masa turunnya, mengkaitkannya dengan sejarah sosial dan intelektual serta tingkat peradaban manusia, serta melihat ayat dari perspektif kemajuan sains dan teknologi. ${ }^{61}$

Begitu gamblang Musdah menjelaskan terkait pentingnya peran akal. hingga di akhir wawancara beliau menegaskan bahwa tanpa peran akal, maka makna ayat tidak akan dapat dipahami secara benar dan holistik. Berikut ungkapannya:

Jadi, sekali lagi peran akal amat penting, tanpanya mustahil makna sebuah ayat dapat dipahami secara benar dan holistik. ${ }^{62}$

Contoh rasio sebagai sumber pemikiran Musdah adalah ketika ia memahami empat jenis istilah kejahatan yang disebutkan dalam Al-Qur'an (al-fahisyah, al-sayyi'at, al-munkar, al-khabaits) itu bersifat umum. Empat kejahatan tersebut tidak hanya dilakukan oleh kelompok homo, tetapi juga dilakukan oleh kelompok hetero, bisek dan aseksual. Dengan kata lain, semua manusia tanpa membedakan bentuk orientasi seksualnya, termsuk kelompok heteroseksual sangat mungkin dan bisa terlibat dalam berbagai bentuk kejahatan seksual (sex crimes) yang diistilahkan dalam empat ungkapan Al-Qur'an di atas. ${ }^{63}$

Banyak contoh dari penafsiran Musdah mengenai rasio sebagai sumber pemikirannya. Hal ini terlihat sangat jelas pada bagian pendapat atau kesimpulan dalam setiap pemaparannya. Bahkan jika dicermati, penggunaan sumber tafsir berupa Al-Qur'an, hadis, dan pendapat mufassir terlebih dahulu, tidak bisa lepas dari unsur ijtihad atau penalaran Musdah Mulia.

c. Empiris

Selain bersumber pada rasio atau akal, penafsiran Musdah Mulia juga bersumber dari data empiris, yakni pengalaman yang pernah dilakukan oleh Musdah Mulia sendiri. Hal ini bisa dilihat ketika Musdah menyatakan bahwa tidak sedikit kelompok homoseksual yang anti sodomi, bahkan mereka anti pada semua bentuk penetrasi penis. Dalam meluapkan nafsunya, mereka hanya melakukan perilaku seksual tanpa menggunakan

\footnotetext{
${ }^{61}$ Hasil wawancara dengan Musdah Mulia, pada tanggal 19 Juni 2018.

${ }^{62}$ Hasil wawancara dengan Musdah Mulia, pada tanggal 19 Juni 2018.

${ }_{63}$ Musdah Mulia, Mengupas Seksualitas: Mengerti Arti, Fungsi, dan Problematika Seksual Manusia Era Kita, Jakarta: Opus Press, 2015, hal. 97-99.
} 
alat kelamin, seperti ciuman, pelukan dan lain sebagainya. Pernyataan ini didasarkan pada pengalamannya, yakni Musdah pernah diundang pada suatu acara pernikahan sesama jenis (laki-laki dengan laki-laki atau gay) di Cape Town, Afrika Selatan, tahun 2011. Laki-laki yang menikah ketika itu bukanlah lelaki biasa, namun seorang ulama di kalangan Muslim Afrika Selatan yang memimpin sebuah organisasi bernama The Inner Circle, Imam Hendrik Muhsin. Seperti acara pernikahan pada umumnya, yakni laki-laki dan perempuan, acara pernikahan sesama jenis itu pun dilakukan dengan menggelar sebuah pesta yang berlangsung selama tujuh hari. ${ }^{64}$

Kemudian Musdah menceritakan bahwasannya Imam Muhsin dan para gay yang tergabung dalam komunitas mereka tidak mempraktikkan sodomi. menurutnya, tidak semua gay melakukan penetrasi, bahkan menbayangkan hal tersebut saja mereka merasa jijik. ${ }^{65}$

Dapat dikatakan, sumber empiris atau pengalaman juga ikut andil dalam mengkonstruk pemikiran Musdah Mulia terhadap homoseksual. Sumber empiris tersebut berfungsi sebagai pendukung atas penafsiran Musdah.

d. Ilmu Pengetahuan Mutakhir (sains)

Terkait dengan sumber temuan ilmu dan sains terbaru, Musdah menyatakan:

Sejauh ini berbagai studi tentang orientasi seksual menyimpulkan ada beberapa varian orientasi seksual, yaitu heteroseksual (hetero), homoseksual (homo), biseksual (bisek), dan aseksual (asek). Boleh jadi dengan perkembangan ilmu pengetahuan dan kemajuan teknologi rekayasa genetika, kelak akan ditemukan bentuk orientasi seksual lain. Sebab, manusia adalah makhluk yang penuh misteri dan sampai sekarang pun masih banyak aspek yang belum terungkap dari diri manusia. Hal itu menunjukkan betapa besar keagungan sang pencipta, Tuhan Yang Maha Kuasa dan betapa kerdilnya manusia sebagai ciptaan-Nya. ${ }^{66}$

Contohnya adalah pemaparan Musdah tentang suatu hasil studi yang dilakukan oleh Alfred Kinsey, pakar biologi dan pionir penelitian seksualitas manusia. Alfred Kinsey mengungkapkan bahwa ternyata tidak ada manusia yang memiliki orientasi heteroseksual $100 \%$ atau orientasi homoseksual

${ }^{64}$ Musdah Mulia, Mengupas Seksualitas: Mengerti Arti, Fungsi, dan Problematika Seksual Manusia Era Kita, Jakarta: Opus Press, 2015, hal. 194.

${ }^{65}$ Musdah Mulia, Mujahidah Muslimah: Kiprah dan Pemikiran Prof. Dr. Siti Musdah Mulia, M.A. Bandung: Nuansa Cendekia, 2013, hal. 197.

${ }^{66}$ Hasil wawancara dengan Musdah Mulia, pada tanggal 27 Januari 2018. 
$100 \%$ atau orientasi seksual lainnya secara penuh, melainkan selalu ada gradasi. Menurutnya, ada skala 7 poin dalam the Kinsey Reports. ${ }^{67}$

Sebagaimana sumber empiris atau pengalaman yang ikut andil dalam mengkonstruk pemikiran Musdah Mulia terhadap homoseksual, demikian juga temuan ilmu dan sains terbaru ini. Ia juga berfungsi sebagai pendukung atas penafsiran Musdah.

Dari penggunaan temuan ilmu dan sains sebagai sumber pengetahuan, maka dapat disimpulkan bahwa corak penafsiran ${ }^{68}$ yang digunakan oleh Musdah Mulia adalah corak tafsir 'ilmi, yaitu penafsiran Al-Qur'an yang menggunakan pendekatan istilah-istilah (term-term) ilmiah dalam rangka mengungkapkan Al-Qur'an, atau dengan istilah lain, tafsir yang berhubungan dengan ilmu pengetahuan (sains). ${ }^{69}$

Selain corak tafsir 'ilmi, dalam pemikiran Musdah, ditemukan pula corak tafsir al-adabi wa al-ijtima'i (tafsir yang berorientasi pada sastra budaya dan kemasyarakatan), yakni karya tafsir yang menitik beratkan pada ketelitian ungkapan-ungkapan redaksi Al-Qur'an yang disusun dengan bahasa yang lugas dan indah dengan menonjolkan tujuan turunnya AlQur'an, lalu mengaplikasikannya dalam kehidupan masyarakat, sejalan dengan perkembangan masyarakatnya. ${ }^{70} \mathrm{Hal}$ ini terlihat dari upaya Musdah memahami sosiologis Islam dan pemecahan agama terhadap problematika modern. Di samping itu, sesuai dengan corak ini Al-Qur'an (nas) diarahkan kepada gaya bahasa yang lebih mudah dicerna, disesuaikan dengan peristiwa sunnah Allah yang terjadi di alam berupa kemasyarakatan dan tatanan peradaban. ${ }^{71}$ Guna mempertegas argumentasi penulis, berikut kutipan penafsiran Musdah Mulia:

${ }^{67}$ Hasil wawancara dengan Musdah Mulia, pada tanggal 27 januari lihat juga: Musdah Mulia, Mengupas Seksualitas: Mengerti Arti, Fungsi, dan Problematika Seksual Manusia Era Kita (Jakarta: Opus Press, 2015), 22.

${ }^{68}$ Corak penafsiran adalah suatu warna, arah atau kecenderungan pemikiran atau ide tertentu yang mendominasi sebuah karya tafsir. Sejalan dengan perkembangan peradaban dan pemikiran seorang mufassir - yang menggunakan basis pengetahuannya sebagai kerangka dalam memahami Al-Qur'an - maka muncullah berbagai corak tafsir, di antaranya: tafsir fiqhi (corak hukum), tafsir falsafi, tafsir 'ilmi, tafsir sufi, dan tafsir al-adabi wa al-ijtima'i serta corak-corak yang lain. (lihat Naqiyah Mukhtar, Ulumul Qur'an (Purwokerto: STAIN Press, 2013), 173; lihat juga Nashruddin Baidan, Wawasan Baru Ilmu Tafsir, cet. ke-2 (Yogyakarta: Pustaka Pelajar, 2011), 388).

${ }^{69}$ Naqiyah Mukhtar, Ulumul Qur'an, Purwokerto: STAIN Press, 2013, hal. 173.

${ }^{70}$ Naqiyah Mukhtar, Ulumul Qur'an (Purwokerto: STAIN Press, 2013), 173.

${ }^{71}$ Mohammad Ridho, Islam, Tafsir dan Dinamika Sosial: Ikhtiar Memaknai Ajaran Islam, Yogyakarta: Teras, 2010, hal. 70-71. 
Salah satu bentuk kebajikan itu adalah mengedepankan perilaku seksual yang tidak mengandung unsur kekerasan dan pemaksaan yang membuat orang lain merasa tidak nyaman atau bahkan tersiksa.

Demikian sumber penafsiran yang mengkonstruk pemikiran Musdah Mulia. Satu hal yang sangat penting, bahwa semua pemikiran Musdah terkait isu kemanusiaan, termsuk seksualitas manusia itu dilandaskan pada konsep tauhid sebagai esensi ajaran Islam. Tauhid mengajarkan bahwa hanya ada satu Tuhan, selain-Nya adalah makhluk belaka. Maka dalam posisi sebagai makhluk, manusia semua adalah setara. Yang terbaik di antara manusia hanya lah mereka yang bertakwa, namun ketakwaan seseorang hanya Allah yg tahu, bukan manusia. Oleh karena itu, dalam posisi sebagai manusia jangan pernah mengadili manusia lainnya. ${ }^{72}$

\section{Metode Penafsiran Musdah Muliah tentang Homoseksual}

Berdasarkan paparan bentuk metode tafsir maudhu'i/tematik pada bab sebelumnya, maka penulis menyimpulkan bahwasannya bentuk metode tafsir tematik yang digunakan oleh Musdah Mulia adalah tematik tema. Secara teknis, langkah-langkah metode tematik yang digunakan oleh Musdah Mulia terhadap ayat-ayat homoseksualitas adalah sebagai berikut ${ }^{73}$ :

a. Menentukan tema dan permasalahan yang akan dibahas. Tema yang digunakan oleh Musdah untuk membahas homoseksual adalah adalah Islam dan Perilaku Seksual. Kemudian ia membaginya ke dalam dua sub tema, yaitu homoseksual bukan liwath dan perlunya membangun kearifan terhadap sesama.

b. Mengumpulkan semua ayat-ayat Quran dan Sunnah Nabi Muhammad saw. yang berhubungan dengan isu homoseksual.

\footnotetext{
${ }^{72}$ Hasil wawancara dengan Musdah Mulia, 6 februari 2018.

${ }^{73}$ Sebagaimana penulis jelaskan pada bab pertama, dalam bab ini penulis tegaskan kembali bahwasannya karya Musdah tentang homoseksual, lebih tepatnya karya Mengupas Seksualitas: Mengerti Arti, Fungsi, dan Problematika Seksual Manusia Era Kita ini secara eksplisit memang bukanlah sebuah karya tafsir sebagaimana karya-karya tafsir yang padanya dinamakan bahwa ia adalah tafsir, sebut saja Tafsir Ibnu Katsir karya Ibnu Katsir. Namun jika ditelisik lebih dalam, karya ini bisa disebut sebagai sebuah penafsiran. Hal ini di dasarkan pada definisi tafsir itu sendiri, bahwa tafsir adalah usaha manusia dalam menemukan maksud-maksud firman Allah Swt. sesuai dengan kemampuan manusia, yang meliputi segala upaya untuk memahami makna (teks) dan menjelaskan maksud (konteks). Usaha inilah yang telah dilakukan oleh Musdah Mulia sehingga menghasilkan karyanya. Upaya penafsiran ini tampak dari bagaimana Musdah Mulia dalam bukunya - khususnya bab homseksual - mencoba untuk memaparkan suatu ayat kemudian menafsirkannya dengan melihat segi sejarahnya, mengutip penafsiran ulama lain, menelitinya dari segi bahasa dan mengkaitkannya dengan konteks sekarang ini. Dengan alasan demikian, menurut hemat penulis buku ini layak untuk disebut sebagai sebuah penafsiran.
} 
c. Seluruh ayat yang sudah dikumpulkan didiskusikan dengan metode tematik.

d. Hasil rumusan langkah ketiga dipantulkan dan dinilai apakah sudah sesuai atau belum dengan nilai-nilai universal al-Quran. Kemudian apakah hasilnya sejalan dengan temuan ilmu dan sains terbaru? Sebab bagi Musdah, hasil penelitian terbaru terkait isu apa pun sangat penting untuk memahami konteks kekinian sebuah isu. Pasalnya, banyak hal yang dulunya dianggap sebagai kebenaran, ternyata penelitian terbaru menyangkalnya. ${ }^{74}$

\section{Validitas Penafsiran Musdah Muliah tentang Homoseksual}

Dalam kajian epistemologi, terdapat tiga teori kebenaran, yakni: teori koherensi (the coherence theory), teori korespondensi (the correspondence theory), dan teori pragmatisme (the pragmatic theory). Berdasarkan ketiga teori kebenaran ini, penulis berpendapat bahwa teori kebenaran yang dominan mewarnai penafsiran Musdah Mulia terhadap ayat-ayat homoseksual adalah teori kebenaran koherensi dan pragmatis.

\section{a. Teori Koherensi}

Penulis berpendapat bahwa Musdah Mulia menganut teori koherensi ini. Hal ini bisa dilihat dari konsistensi penafsiran yang dibangun oleh Musdah. Dalam penafsirannya, Musdah konsisten dalam mengungkapkan bahwa homoseksual bukanlah liwath atau sodomi. Homoseksual berbeda dengan liwat. Liwath adalah "perilaku seksual" yang menyasar ke anus, bukan vagina, sedangkan homoseksual adalah "orientasi seksual" kepada sesama jenis. Di samping itu, liwath (sodomi) bisa dilakukan oleh kaum homoseksual maupun heteroseksual, bahkan biseksual. Yang dikecam dalam Al-Qur'an adalah perbuatan sodomi, bukan homoseksual. Kaum homoseksual belum tentu melakukan sodomi. Oleh sebab itu kaum homoseksual tidak sepatutnya diperlakukan seperti kaum sodomi, apa pun bentuknya, seperti pelecehan, kekerasan, pengucilan, diskriminasi, dan stigmatisasi.

Musdah Mulia konsisten dengan paradigma yang diusungnya, yaitu perlindungan dan pemenuhan terhadap hak-hak asasi setiap manusia, tanpa kecuali sedikit pun, termsuk hak-hak seksual manusia. Di samping itu, landasan pemikiran yang dibangun oleh Musdah Mulia sangat kuat, yakni konsep tauhid sebagai esensi ajaran Islam. Salah satu refleksi konsep Tauhid itu sendiri adalah tidak ada yang berhak menghakimi dan menghukumi

\footnotetext{
${ }^{74}$ Hasil wawancara dengan Musdah Mulia, 6 februari 2018.
} 
manusia selain Allah Swt. Oleh sebab itu, semua penafsirannya akan terbingkai pada konsep tersebut.

\section{b. Teori Pragmatisme}

Penulis berpendapat bahwa penafsiran Musdah cenderung menggunakan teori pragmatisme. Hal ini terlihat dari penafsirannya yang menyatakan bahwa apa pun bentuk orientasi seksual manusia, baik itu hetero, homo, bisek dan aseksual sudah seharusnya mengedepankan perilaku seksual yang sehat, aman, dan bertanggung jawab, tidak mengandung unsur kekerasan dan pemaksaan yang membuat orang lain merasa tidak nyaman atau bahkan tersiksa. $^{75}$

Di samping itu, Musdah menyatakan bahwa semestinya kita mempunyai kesadaran untuk tidak melakukan stigma, diskriminasi, dan kekerasan terhadap sesama manusia, termsuk kaum homoseksual selama mereka tidak melanggar hukum. Itulah pesan utama kenabian dan menjadi esensi ajaran semua agama. Kesadaran itu tidak muncul begitu saja, melainkan harus ditumbuhkan dan dibangun melalui pendidikan formal di sekolah, pendidikan non formal di masyarakat, dan pendidikan dalam keluarga. ${ }^{76}$ Tidak sepatutnya kita mengambil posisi Tuhan, mengadili, menyalahkan dan menghukumi kaum homoseksual. Di hadapan Tuhan, posisi manusia adalah sama. Yang membedakan derajat mereka hanyalah ketakwaan mereka, dan ketakwaan seseorang hanya Allah yang tahu. ${ }^{77}$

Terkait dengan kebenaran tafsir, Musdah menyatakan bahwa dalam menafsirkan teks keagamaan, tidak ada dan tidak diizinkan untuk mengklaim memiliki kebenaran mutlak. Sehingga sebuah pemikiran tidak terjebak pada sebuah pengakuan sebagai juru bicara Tuhan yang paling benar dan menafikan pandangan yang lain, padahal hal tersebut didapat menurut kapasitas dan kapabilitas dalam menjangkau makna sebuah teks keagamaan. Dalam upayanya, Musdah terus bebricara lantang supaya masyarakat mengkaji ajaran agama agar senantiasa relevan dengan perkembangan zaman. Ia juga secara tegas menolak kekeliruan mematikan tentang syariat sebagai hukum moral Ilahi yang abadi dan fikih sebagai

${ }^{75}$ Musdah Mulia, Mengupas Seksualitas: Mengerti Arti, Fungsi, dan Problematika Seksual Manusia Era Kita, Jakarta: Opus Press, 2015, hal. 97.

${ }_{76}$ Musdah Mulia, Mengupas Seksualitas: Mengerti Arti, Fungsi, dan Problematika Seksual Manusia Era Kita, Jakarta: Opus Press, 2015, hal. 98.

77 Musdah Mulia, Mengupas Seksualitas: Mengerti Arti, Fungsi, dan Problematika Seksual Manusia Era Kita, Jakarta: Opus Press, 2015, hal. xii. 
legislasi manusia yang dirancang untuk menjawab problema-problema setiap zaman yang dihadapi oleh makhluk Ilahi yang selalu memperbaharui diri. $^{78}$

Untuk memudahkan pembaca dalam memahami epistemologi penafsiran Musdah Mulia terhadap Ayat-Ayat Homoseksual, dapat dilihat dari tabel di bawah ini:

Tabel IV. 1. Validitas Penafsiran Musdah Mulia

\begin{tabular}{|l|l|l|}
\hline $\begin{array}{c}\text { Sumber Pengetahuan } \\
\text { dalam Penafsiran }\end{array}$ & \multicolumn{1}{|c|}{ Metode Penafsiran } & Validitas Penafsiran \\
\hline$>$ Teks & \multicolumn{1}{|c|}{$\begin{array}{l}\text { Metode Tafsir Tema-tik } \\
>\text { Rasio }\end{array}$} & $>$ Teori Kebenaran Ko-herensi \\
$>$ Empiris & $>$ Teori Kebenaran Pra-gmatis \\
$\begin{array}{l}>\text { Ilmu Pengetahuan } \\
\text { Mutakhir (Sains) }\end{array}$ & & \\
\hline
\end{tabular}

\section{Kesimpulan}

Berdasarkan ulasan yang tertulis di atas maka dapat ditarik beberapa kesimpulan, di antaranya:

1. Sumber penafsiran yang digunakan oleh Musdah Mulia ialah sumber tafsir $b i$ al-ra'yi, yaitu pikiran atau nalar. Adapun komponen-komponennya adalah teks, rasio, empiris dan Ilmu Pengetahuan Mutakhir (sains). Sedangkan corak yang digunakan adalah corak tafsir 'ilmi.

2. Metode tafsir yang digunakan Musdah Mulia adalah tafsir tematik (maudhu'i), holistik yaitu berupa cakupan seluruh ilmu meliputi metodologi tafsir, kaidah dan teori ushul fiqh, kaidah dan teori dalam ilmu tafsir, ilmu filsafat, sosial dan sains, dan tafsir kontekstual (sosio-historis) yaitu dengan memahami makna ayat-ayat Al-Qur'an dengan memperhatikan dan mengkaji keterkaitannya dengan peristiwa atau situasi yang melatarbelakangi turunnya ayat tersebut atau dengan mengkaji konteksnya.

3. Bahwa validitas penafsiran Musdah Mulia adalah cenderung pada teori koherensi dan teori pragmatisme. Dari aspek koherensi bisa dilihat dari konsistensi penafsirannya dalam mengungkapkan bahwa homoseksual bukanlah liwath atau sodomi, melainkan orientasi seksual yang sifatnya

${ }^{78}$ Musdah Mulia, Mujahidah Muslimah: Kiprah dan Pemikiran Prof. Dr. Siti Musdah Mulia, M.A. Bandung: Nuansa Cendekia, 2013, hal. 129. 
kodrati. Sedangkan dari aspek teori pragmatis, dapat dilihat dari penafsirannya yang menyatakan bahwa apapun bentuk orientasi seksual manusia, sudah seharusnya mengedepankan perilaku seksual yang sehat, aman, dan bertanggung jawab. Termasuk juga dengan pernyataannya bahwa semestinya setiap manusia mempunyai kesadaran untuk tidak melakukan stigma, diskriminasi, dan kekerasan terhadap sesama manusia, termasuk kaum homoseksual selama mereka tidak melanggar hukum.

\section{Daftar Pustaka}

'Aidi, Muhammad 'Audhal Al-Fihrisu Al-Maudhu'i li Al-Ayati Al-Qur'an Al-Karimi, Kairo: Markaz al-Kitaba li An-Nasyri, 2004

Agama RI, Departemen Membangun Keluarga Harmonis: Tafsir Al-Qur'an Tematik, Jakarta: Departemen Agama RI, 2008.

Agama RI, Kementrian Tafsir Ilmi: Seksualitas dalam Perspektif Al-Qur'an dan Sains, Jakarta: Lajnah Pentashihan Mushaf Al-Qur'an, 2012.

Aini, Ira D. Mujahidah Muslimah: Kiprah dan Pemikiran Prof. Dr. Siti Musdah Mulia, M.A,. Bandung: Nuansa Cendekia, 2013.

Al-Abyari, Ibrahim Al-Mausu'ah Al-Qur'aniyyah, Kairo: Dar Al-Kitab Al-Misri, 1984, vol, 7.

Al-Alusi, Ruh Al-Ma'ani fi Tafsiri Al-Qur'an al-'adzim wa al-Sab'i al-Matsani, Bairut: Dar Ihya' aliTurats al-'Arabi, 1985.

Andina, Elga "Faktor Psikologi dalam Interaksi Masyarakat dengn Gerakan LGBT di Indonesia", Jurnal Aspirasi, Vol.7 No. 2, Desember 2016.

Anshari, Endang Saifuddin Ilmu Filsafat dan Agama, Surabaya: PT Bina Ilmu, 1982

Arroudho, Khulaipah "Epistemologi Penafsiran Olfa Youssef dalam Konstruksi Seksualitas Ayat-ayat al-Jinsiyyah al-Mitsliyyah", dalam tesis UIN Sunan Kalijaga Yogyakarta, 2017.

as-Suyuthi, ad-Durru al-Mantsur fi al-Tafsiri al-mantsur, Bairut: Dar al-Kutub al 'Ilmiyah, 1990.

as-Syafi'i, Husain Muhammad Fahmi Ad-Dalil Al-Mufahras li Al-Fadzi Al-Qur'an AlKarimi, Kairo: Dar as-Salam, 2008.

Audah, Ali Korkondansi Qur'an: Panduan Kata dalam Ayat Qur'an Cet. 4, Bogor: Pustaka Litera Antar Nusa, 2008.

az-Zahabi, Muhammad Husain at-Tafsir wa al-Mufassirun, juz 1, Kairo: Dar al-Hadis, 2005.

Baidan, Nashruddin Wawasan Baru Ilmu Tafsir, cet. ke-2 Yogyakarta: Pustaka Pelajar, 2011.

Baqi, Muhammad Fuad 'Abdul “Al-Mu'jam Al-Mufahras Li Alfadz Al-Qur'an Al-Karimi, Kairo: Dar al-Hadis, 2001.

Beaume, Jules La Tafsil Ayati Al-Qur'an Al-Hakim, terj. Muhammad Fuad 'Abdul Baqi, Mesir: Dar al-wahyi al-Muhammadi. 
Biyanto, Filsafat Ilmu dan Ilmu Keislaman, Yogyakarta: Pustaka Pelajar, 2015.

Bouhdiba, Abdelwahab Sexuality in Islam: Peradaban Kamasutra Abad Pertengahan, terj. Ratna Maharani Utami, Yogyakarta: Alenia.

Burhanuddin, Nunu "Pemikiran Epistemologi Barat: dari Plato Sampai Gonseth", Jurnal Intizar, Vol. 21, No. 1, 2015.

Fawdah, Mahmud Basuni Tafsir-tafsir Al-Qur'an: Perkenalan dengan Metodologi Tafsir terj. M. Mochtar Zoemi dan Abdul Qadir Hamid, Bandung: Pustaka, 1987.

Gunawan, Rudi filsafat Seks, Yogyakarta: Bentang, 1993.

Hadna, Ahmad Musthafa Problematika Menafsirkan Al-Qur'an, Semarang: Dina Utama Semarang, 1993.

Hastuti Ratri Endah Mastuti, Rachmad Djati Winarno, Lita Widyo "Pembentukan Identitas Orientasi Seksual pada Remaja Gay" Jurnal Prediksi, Kajian Ilmiah Psikologi - No. 2, Vol . 1, Juli - Desember 2012.

Hathout, Abdullah Nashih Ulwan, Hassan Pendidikan Anak Menurut Islam Pendidikan Seks, terj. Khalilullah Ahmas Masjkur Hakim dan Jalaludin Rahmat, Bandung: PT Rosdakarya, 1992.

Kencana, Rama Azhari dan Putra Membongkar Rahasia Jaringan Cinta Terlarang Kaum Homoseksual, Jakarta: Hujjah Press, 2008.

Masthuriyah Sa'dan, Lgbt Dalam Perspektif Agama dan Ham, Jurnal Nizham, Vol. 05, No. 01 Januari-Juni 2016.

Muhammad et al, Husain Fiqih Seksualitas: Risalah Islam dalam Pemenuhan Hak-Hak Seksual, t.tp.: PKBI, t.t.

Mukhtar, Naqiyah Ulumul Qur'an Purwokerto: STAIN Press, 2013.

Mulia, Musdah Mengupas Seksualitas: Mengerti Arti, Fungsi, dan Problematika Seksual Manusia Era Kita, Jakarta: Opus Prees, 2015.

Mustaqim, Abdul "Homoseksual Dalam Perspektif Al-Qur'an: Pendekatan Tafsir Kontekstual al-Maqashidi," Jurnal Suhuf, Vol.9, No.1, Juni 2016.

Mustaqim, Abdul Epistemologi Tafsir Kontemporer, Yogyakarta: LkiS Group, 2012.

Nata, Abuddin Islam dan Ilmu Pengetahuan, Jakarta: Prenadamedia Group, 2018.

Nawawi, Abd. Muid "Hermeneutika Tafsir Maudhu'i”, Jurnal Suhuf, Volume 9, Nomor 1, Juni 2016.

Pranata, Tommy Dwi "Perilaku dan Realitas Sosial Kehidupan Gay di Kota Samarinda", e-Journal Sosiatri-Sosiologi, Vol. 3, 2015, 140.

Rachmat dkk., Aceng Filsafat Ilmu Lanjutan, Jakarta: Kencana, 2011.

Rahardjo, M. Dawam Ensiklopedi Al-Qur'an: Tafsir Sosial Berdasarkan Konsep-konsep kunci, cet, II, Jakarta: Paramadina, 2002.

Ridho, Mohammad Islam, Tafsir dan Dinamika Sosial: Ikhtiar Memaknai Ajaran Islam, Yogyakarta: Teras, 2010.

Rohmawati, "Perkawinan Lesbian, Gay, Biseksualdan Transgender/Transeksual (Lgbt) Perspektif Hukum Islam" Jurnal Ahkam, Volume 4, Nomor 2, November 2016.

Salim Nst, Agus "Homoseksual dalam Pandangan Hukum Islam", Jurnal Ushuluddin Vol. XXI No. 1, Januari 2014.

Santoso dkk., Listiyono Epistemologi Kiri, Yogyakarta: Ar-Ruzz Media, 2003. 
Soleh, A. Khudori integrasi Agama \& Filsafat Pemikiran Epistimologi al-Farabi (Malang: UIN-MALIKI Press, 2010).

Surajiyo, Ilmu Filsafat Suatu Pengantar, Jakarta: PT Bumi Aksara.

UGM, Tim Dosen Filsafat Ilmu Fakultas Filsafat Filsafat Ilmu (Yogyakarta : Liberty, 1996).

Umar, Nasaruddin Argumen Kesetaraan Gender Persepektif Al-Qur'an, Jakarta: Paramadina, 2001.

Wijaya, Aksin Nalar Kritis Epistemologi Islam Membincang Dialog Kritis Para Kritikus Muslim: Al-Ghazali, Ibnu Rusyd, Thaha Husein, dan Muhammad Abid al-Jabiri Yogyakarta: Kalimeda, 2017.

Yurni, "Gambaran Perilaku Seksual dan Orientasi Seksual Mahasiswa di Kota Jambi” Jurnal Ilmiah Dikdaya. 